\title{
Testing the Influence of the Quality of the Supply Voltage on the Performance of a Numerical Relay
}

\author{
Ruth P.S. Leão ${ }^{1}$, Ana L.Colaço ${ }^{2}$, Nelber X. Melo ${ }^{1}$, Janaína A. Almada ${ }^{1}$, Robson A. Azevedo ${ }^{1}$, Raimundo F. \\ Sampaio $^{1}$, Giovanni C. Barroso ${ }^{1}$ e José Giordane Silveira ${ }^{2}$ \\ ${ }^{1}$ Department of Electrical Engineering - DEE \\ Federal University of Ceará - UFC \\ Campus do Pici - Fortaleza, Ceará (Brazil) \\ Phone/Fax number: +55 85 33669576/:+55 85 33669574, e-mail: rleao@dee.ufc.br, nelber@dee.ufc.br, \\ janainaaalmada@oi.com.br, robsonaazevedo@gmail.com,rfurtado@dee.ufc.br, gcb@fisica.ufc.br \\ ${ }^{2}$ Energy Company of Ceará - COELCE \\ Rua Padre Valdevino, 150 - Fortaleza, Ceará (Brazil) \\ Phone/Fax number: +55 85 34534162, e-mail: anacolaco@coelce.com.br, giordane@coelce.com.br
}

\begin{abstract}
To ensure consistent reliability and proper operation, protective relay equipment must be evaluated and tested. This paper presents the requirements for testing the ac and d.c. auxiliary power supply of protective relays and the test results. The test severity levels, test set-up, test procedures and test report are presented according to the IEC60255-11 Ed.2.0. A numerical relay commonly found in the power distribution systems is used for testing. The tests are carried out to determine the ability of the relay to withstand a variety of disturbances as specified in the international standard.
\end{abstract}

\section{Key words}

Conformity test, programmable power source, protective relaying, power disturbances, voltage interruption, voltage sag.

\section{Introduction}

The last decades have seen enormous changes in relay technology evolving from electromechanical, static, digital, to numerical relays. The numerical relays have revolutionized protection, control, non-revenue metering, oscillography and communication in power systems. Functional integration, multifunction, new methods of communication, reduced physical size, and a vast amount of available information are but a few of the benefits of this revolution [1]. Historically, protection, control, oscillography and metering subsystems were comprised of separate devices, each designed with a specific purpose in mind. Today, protection, control, metering and a wide range of other tasks can be performed by a single numerical relay also referred to as Intelligent Electronic Device (IED). The use of IEDs and complex communication networks can bring together unprecedented capabilities in protection, control, and monitoring of all power delivery utilities [2].
Since the protection relays are required to operate correctly under abnormal system conditions, it is essential that their operation is guaranteed under such conditions [3], [4], [5].

This paper deals with the requirements for testing the ac and dc power supply of relays for power system protection based on the international standard IEC6025511 Edition 2.0 2008-10 [6]. The purpose of testing protective relays is to ensure correct operation of the relay for all possible power system conditions and disturbances. The objective of the tests is to appraise whether the protective relay will operate correctly when energized and subjected to voltage sags, voltage short interruptions, alternating components in dc (ripple), gradual shut-down/start-up test and polarity inversion. A programmable source is used to generate the disturbance types applied to the relays input power supplies. The test results are presented according to the acceptance criteria established in the international standard.

\section{Numerical Relay Technology}

The typical architecture of a numerical relay consists of one or more DSP microprocessors as the computation hardware along with the associated software tools, some memory, digital and analogue input/output (I/O), external communication ports, HMI display and a power supply. By using multiple microprocessors to provide the necessary computational performance, a large number of functions previously implemented in separate items of hardware can be included within a single item. Typical functions that may be found in a numerical relay besides protection functions (such as directional/nondirectional overcurrent protection, distance protection, undervoltage protection, negative sequence current protection, reclosing, etc.) include several setting groups for protection values, measurement of power system 
quantities (current, voltage, etc.), fault/event/disturbance recorder, self-monitoring, internal fault diagnosis, circuitbreaker monitoring (state, condition, control), voltage transformer supervision, etc. Not all functions may be found in a particular relay, nevertheless the protection relay no longer performs a basic protection function, but is becoming an integral and major part within the overall network automation scheme.

As the protection relay is probably the only device that is virtually mandatory on circuits of any significant rating, the functions previously carried out by separate devices are now found in a protection relay permitting significant cost savings and wiring simplification as compared with discrete protective relays, instruments, meters, recorders, and transducers of the past [7].

\section{Relays Power Supplies}

The protective relays can be powered by either an ac or a dc power supply as illustrated in Fig.1.

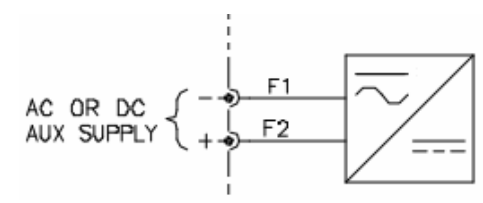

Fig. 1. An illustration of an ac. and dc auxiliary power supply.

The auxiliary supply can be supplied from a number of sources or safe supplies such as batteries, uninterruptible power supplies, generators, etc. When the energizing input is a dc power supply the relays generally require a reliable source of dc power and measures to prevent damage to internal circuitry had to be devised. Substation environments are particularly hostile to electronic circuits due to electrical interference of various forms that are commonly found (e.g. switching operations and the effect of faults). The relays must be therefore immune to conducted and radiated interference from the electrically noisy substation environment. While it is possible to arrange for the dc supply to be generated from the measured quantities of the relay, this has the disadvantage of increasing the burden on the current transformers (CT) or voltage transformers (VT), and there will be a minimum primary current or voltage below which the relay will not operate. This directly affects the possible sensitivity of the relay. So provision of an independent, highly reliable and secure source of relay power supply is an important consideration. To prevent mal-operation or destruction of electronic devices during faults or switching operations, sensitive circuitry is housed in a shielded case to exclude common mode and radiated interference. Since the protection relays are required to operate correctly under abnormal system conditions, it is essential that their operation is guaranteed under such conditions.

\section{Relay Testing}

The relay used in the tests has the protection functions of over-current, directional and non-directional, instantaneous and time-delayed; over-voltage and undervoltage; under-frequency and over-frequency. The relay can be programmed to various other logic functions. It can also provide both primary and secondary measuring data, such as currents and phase voltages and calculated values as power, frequency, energy, etc. Both the steadystate and disturbance signals can be viewed and stored in mass memory and presented as oscillography.

The testing of protection relays is needed in order to evaluate the relay performance and characteristics and to certify the equipment compliance to the requirements of technical standards. The testing of protection relays may be divided into four stages: type tests, routine factory production tests, commissioning tests and periodic maintenance tests. Type tests are required to prove that a relay meets the published specification and complies with all relevant standards. Routine factory production tests are conducted to prove that relays are free from defects during manufacture. Testing will take place at several stages during manufacture. Commissioning tests are designed to prove that a particular protection scheme has been installed correctly prior to setting to work. Periodic maintenance checks are required to identify equipment failures and degradation in service, so that corrective action can be taken. This paper deals with type testing on the auxiliary power supply of protective relays [8].

\section{A. Auxiliary Power Supply Type Test}

The auxiliary power supply port may be subject to voltage sags, short interruptions and voltage variations. Relays are designed to ensure that operation is maintained and no damage occurs during a disturbance of the auxiliary supply.

Tests are carried out for both ac and dc auxiliary supplies. The test is specified in IEC 60255-11 Edition $2.02008-10$ [6] and the type, levels and duration of tests are given in Table I. This latest edition has replaced the previous one published in 1979 and it adds voltage dips and interruptions test in ac, gradual shut-down/start-up test, and reversal of dc power supply polarity test. Also the level of the ripple component has been included.

The disturbances should not cause any malfunction in the relay operation. Malfunctions include the operation of output relays and watchdog contacts, the reset of microprocessors, alarm or trip indication, acceptance of corrupted data over the communication link and the corruption of stored data or settings.

The voltage dip and voltage interruption tests are to determine the maximum time-length that a relay can withstand a dip/interruption in the auxiliary supply without de-energising and that when this time is exceeded and it does transiently switch off, that no misoperation occurs. 
Table I. - Type, level and duration of tests

\begin{tabular}{|c|c|c|}
\hline TYPE OF PHENOMENA & $\begin{array}{c}\text { TEST } \\
\text { SPECIFICATIONS } \\
\end{array}$ & UNITS \\
\hline \multirow{3}{*}{$\begin{array}{l}\text { Voltage dips } \\
\text { (for dc power } \\
\text { supply) }\end{array}$} & $\begin{array}{c}0 \\
10 \text { to } 1000\end{array}$ & $\begin{array}{l}\text { \% residual } \\
\text { voltage } \\
\text { ms }\end{array}$ \\
\hline & $\begin{array}{r}40 \\
200 \\
\end{array}$ & $\begin{array}{c}\text { \% residual } \\
\text { voltage } \\
\text { ms } \\
\end{array}$ \\
\hline & $\begin{array}{l}70 \\
500\end{array}$ & $\begin{array}{l}\text { \% residual } \\
\text { voltage } \\
\text { ms }\end{array}$ \\
\hline \multirow{3}{*}{$\begin{array}{c}\text { Voltage dips } \\
\text { (for ac power supply) }\end{array}$} & $\begin{array}{c}0 \\
0,5 \text { to } 25 \\
\end{array}$ & $\begin{array}{l}\text { \% residual } \\
\text { voltage } \\
\text { cycles }\end{array}$ \\
\hline & $\begin{array}{c}40 \\
10 / 12 \text { at } 50 / 60 \mathrm{~Hz} \\
\end{array}$ & $\begin{array}{c}\text { \% residual } \\
\text { voltage } \\
\text { cycles } \\
\end{array}$ \\
\hline & $\begin{array}{c}70 \\
25 / 30 \text { at } 50 / 60 \mathrm{~Hz}\end{array}$ & $\begin{array}{l}\text { \% residual } \\
\text { voltage } \\
\text { cycles }\end{array}$ \\
\hline $\begin{array}{l}\text { Voltage interruptions } \\
\text { (for dc power } \\
\text { supply) } \\
\end{array}$ & $\begin{array}{l}0 \\
5 \\
\end{array}$ & $\begin{array}{c}\text { \% residual } \\
\text { voltage } \\
\mathrm{s} \\
\end{array}$ \\
\hline $\begin{array}{l}\text { Voltage interruptions } \\
\text { (for ac power supply) }\end{array}$ & $\begin{array}{c}0 \\
250 / 300 \text { at } 50 / 60 \mathrm{~Hz} \\
\end{array}$ & $\begin{array}{l}\text { \% residual } \\
\text { voltage } \\
\text { cycles }\end{array}$ \\
\hline $\begin{array}{c}\text { Alternating } \\
\text { component in dc } \\
\text { (ripple) } \\
\text { (for dc power } \\
\text { supply) }\end{array}$ & $\begin{array}{c}15 \% \text { of rated dc } \\
\text { value } \\
100 / 120 \text { at } 50 / 60 \\
\mathrm{~Hz}\end{array}$ & $\begin{array}{c}\text { V } \\
\text { Hz, sinusoidal } \\
\text { waveform }\end{array}$ \\
\hline $\begin{array}{l}\text { Gradual shut- } \\
\text { down/start-up } \\
\text { (for dc power } \\
\text { supply) } \\
\end{array}$ & $\begin{array}{c}60 \\
5 \\
50 \\
60\end{array}$ & $\begin{array}{c}\text { s, shut-down } \\
\text { ramp } \\
\text { min, power off } \\
\text { s, start-up ramp }\end{array}$ \\
\hline $\begin{array}{c}\text { Reversal of dc power } \\
\text { supply polarity }\end{array}$ & 1 & $\min$ \\
\hline
\end{tabular}

The ac ripple superimposed on dc supply test determines that the relay is able to operate correctly with a superimposed ac voltage on the dc supply. This is caused by the station battery being charged by the battery charger.

The gradual shut-down/start-up test simulates a failed station battery charger, which would result in the auxiliary voltage to the relay slowly ramping down. The ramp up part simulates the battery being recharged after discharging. The relay must power up cleanly when the voltage is applied and it must not misoperate.

\section{B. Criteria for Acceptance}

As aforementioned the numerical relays perform many functions besides protection. The criteria for acceptance are classified in two groups, A and C, each of it taking the protection, command and control, integral humanmachine interface and visual alarms and data communication into account. The criterion A is related to the relay response to the ac and dc power supply voltages to $0 \%$ and the criterion $\mathrm{C}$ in turn is related to the other types of phenomena. The criteria are given in Table II.
The tests should be carried out at the following conditions: the protection relay shall be in a quiescent state, half of the binary inputs and half of the output relays shall be energized and the communication modules, if any, shall be activated.

\section{Test Set-up}

An ac/dc programmable source has been used to generate the disturbances to test the relay compliances to the international standard. The equipment under test is a multifunction overcurrent numeric relay. The relay functions besides the overcurrent functions, directional and non-directional, it has the function as reclosing, sensitive neutral, logic selectivity, current unbalance, oscillography and power and energy measurements. The relay used for testing has the specification shown in Table III.

The effects of the tests should be assessed at the maximum and minimum values of the voltage according to the relay technical documentation.

The voltages in the IEC60255-11 use the rated voltage for the equipment as a basis for voltage test level specification. Where the equipment has a rated voltage range, the test procedure shall be applied for both the lowest and highest voltages declared in the voltage range.

\section{Test Results}

Tests have been carried out with a voltage of 110 Vac applied to the relay measurement input voltage. The relay has been kept in a quiescent state according to the standard recommendation. The test bench is shown in Fig.2.

\section{A. Voltage dip testing to the dc power supply}

Table IV presents the test results for the applied dc voltage dips to $0 \%, 40 \%$ and $70 \%$ to the relay lowest and highest voltage operation range, i.e., $\mathrm{Vmin}=87 \mathrm{Vdc}$ and Vmax $=300$ Vdc. As shown in Table IV, different time duration has been tested for a voltage dip to $0 \%$.

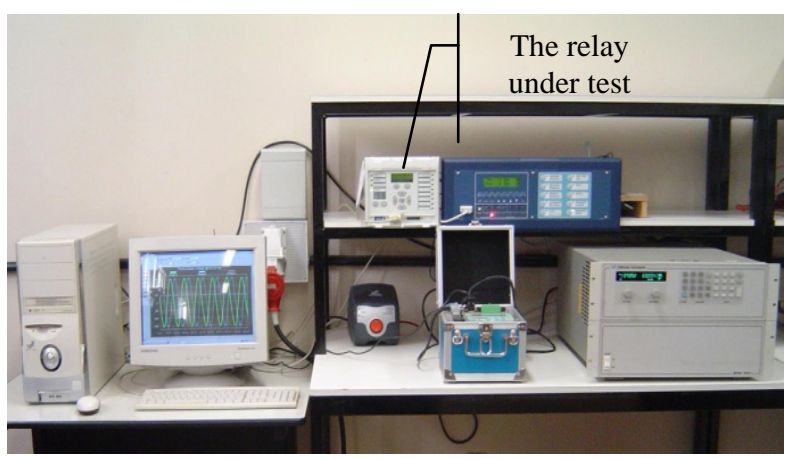

Fig.2. Workbench test. 
Table II. - Criteria for acceptance

\begin{tabular}{|c|c|c|}
\hline CRITERION & FUNCTION & CRITERION FOR ACCEPTANCE \\
\hline \multirow[t]{5}{*}{ A } & Protection & $\begin{array}{l}\text { Normal performance within } \\
\text { the specification limits, } \\
\text { during and after the test. }\end{array}$ \\
\hline & $\begin{array}{l}\text { Command and } \\
\text { control }\end{array}$ & $\begin{array}{l}\text { Normal performance within } \\
\text { the specification limits, } \\
\text { during and after the test. }\end{array}$ \\
\hline & Measurement & $\begin{array}{l}\text { Temporary degradation } \\
\text { during test, with self- } \\
\text { recovery at the end of the } \\
\text { test. No loss of stored data. }\end{array}$ \\
\hline & $\begin{array}{l}\text { Integral human- } \\
\text { machine } \\
\text { interface and } \\
\text { visual alarms }\end{array}$ & $\begin{array}{l}\text { Temporary degradation or } \\
\text { loss of function during test, } \\
\text { with self-recovery at the end } \\
\text { of the test. No loss of stored } \\
\text { data. }\end{array}$ \\
\hline & $\begin{array}{l}\text { Data } \\
\text { communication }\end{array}$ & $\begin{array}{l}\text { Possible bit error rate } \\
\text { increase but no loss of } \\
\text { transmitted data. }\end{array}$ \\
\hline \multirow[t]{5}{*}{$\mathrm{C}$} & Protection & $\begin{array}{l}\text { Normal performance within } \\
\text { the specification limits, or a } \\
\text { predefined behavior, e.g. } \\
\text { temporary loss of function } \\
\text { or switch-off, which is } \\
\text { clearly specified by the } \\
\text { manufacturer until normal } \\
\text { operation is automatically } \\
\text { resumed. There shall be no } \\
\text { unwanted operation. }\end{array}$ \\
\hline & $\begin{array}{l}\text { Command and } \\
\text { control }\end{array}$ & $\begin{array}{l}\text { Normal performance within } \\
\text { the specification limits, or a } \\
\text { predefined behavior, e.g. } \\
\text { temporary loss of function } \\
\text { or switch-off, which is } \\
\text { clearly specified by the } \\
\text { manufacturer until normal } \\
\text { operation is automatically } \\
\text { resumed. There shall be no } \\
\text { unwanted operation. }\end{array}$ \\
\hline & Measurement & $\begin{array}{l}\text { Temporary degradation } \\
\text { during test, or a predefined } \\
\text { behavior, e.g. temporary loss } \\
\text { of function, which is clearly } \\
\text { specified by the } \\
\text { manufacturer until normal } \\
\text { operation is automatically } \\
\text { resumed. }\end{array}$ \\
\hline & $\begin{array}{l}\text { Integral human- } \\
\text { machine } \\
\text { interface and } \\
\text { visual alarms }\end{array}$ & $\begin{array}{l}\text { Temporary degradation } \\
\text { during test, or a predefined } \\
\text { behavior, e.g. temporary loss } \\
\text { of function or switch-off, } \\
\text { which is clearly specified by } \\
\text { the manufacturer until } \\
\text { normal operation is } \\
\text { automatically resumed. }\end{array}$ \\
\hline & $\begin{array}{l}\text { Data } \\
\text { communication }\end{array}$ & $\begin{array}{l}\text { Possible bit error rate } \\
\text { increase, or a predefined } \\
\text { behavior, e.g. loss of data, } \\
\text { which is clearly specified by } \\
\text { the manufacturer until } \\
\text { normal operation is } \\
\text { automatically resumed. }\end{array}$ \\
\hline
\end{tabular}

Table III. - The relay power supply voltage specification

\begin{tabular}{|c|c|c|}
\hline DEVICES & AUXILIARY VOLTAGE & OPERATION RANGE \\
\hline Relay & 110 to 250 Vdc & 87 to $300 \mathrm{Vdc}$ \\
& 100 to $240 \mathrm{Vac}(\mathrm{rms})$ & 80 to $265 \mathrm{Vac}$ \\
\hline
\end{tabular}

Table IV. - Voltage dip test applied to the dc energizing input Vmin=87 Vdc and Vmax=300 Vdc.

\begin{tabular}{|c|c|c|c|}
\hline \multirow{2}{*}{$\begin{array}{c}\text { DC voltage DIP TO } \\
(\%)\end{array}$} & $\begin{array}{c}\text { TeSt DURATION } \\
(\mathrm{ms})\end{array}$ & \multicolumn{2}{|c|}{$\begin{array}{c}\text { TEST } \\
\text { CONCLUSION }\end{array}$} \\
\cline { 3 - 4 } & 10 & VMIN & VMAX \\
\hline & 20 & Pass & Pass \\
& 30 & Pass & Pass \\
& 50 & Pass & Pass \\
& 100 & Pass & Pass \\
0 & 200 & Fail & Pass \\
& 300 & Fail & Pass \\
& 500 & Fail & Pass \\
& 1000 & Fail & Pass \\
\hline 40 & 200 & Fail & Pass \\
\hline 70 & 500 & Pass & Pass \\
\hline
\end{tabular}

For the lowest voltage, voltage dips to $0 \%$ with time duration exceeding $200 \mathrm{~ms}$, inclusive, has led the relay to a temporarily loss of function - the relay automatically switched-off resuming the functions at the end of the test, except its communication with the software that had to manually be re-established.

\section{B. Voltage dip test on the ac power supply}

Table $\mathrm{V}$ shows the test conclusion when the ac voltage dips to 0,40 and $70 \%$ have been applied to the relay ac power supply for the minimum and maximum voltage operation range of $80 \mathrm{Vac}$ and $265 \mathrm{Vac}$, respectively.

The relay has failed, switching it off when a voltage dip to $0 \%, 25$ cycles, was applied for a reference ac voltage of $80 \mathrm{Vac}$. The relay has operated normally to the other conditions.

Table V. - Voltage dip test for ac energizing input at Vmin=80 Vac and $V m a x=265 V$.

\begin{tabular}{|c|c|c|c|}
\hline \multirow{2}{*}{$\begin{array}{c}\text { DC VOlTAGE DIP TO } \\
(\%)\end{array}$} & \multirow{2}{*}{$\begin{array}{c}\text { TeST DURATION } \\
\text { (CYCLES) }\end{array}$} & \multicolumn{2}{|c|}{$\begin{array}{c}\text { TEST } \\
\text { CONCLUSION }\end{array}$} \\
\cline { 3 - 4 } & & VMIN & VMAX \\
\hline & 0.5 & Pass & Pass \\
& 1 & Pass & Pass \\
0 & 2.5 & Pass & Pass \\
& 5 & Pass & Pass \\
& 10 & Pass & Pass \\
& 25 & Fail & Pass \\
\hline 40 & 12 & Pass & Pass \\
\hline 70 & 30 & Pass & Pass \\
\hline
\end{tabular}

\section{Voltage interruption testing the dc. power supply}

Short voltage interruption of $5 \mathrm{~s}$ duration has been applied to the relay dc input, considering the lowest and the highest voltage operation range. The relay has failed during the test as presented in Table VI. 
Table VI. - Voltage interruption test for dc energizing input at Vmin=87 Vdc and Vmax=300 Vdc.

\begin{tabular}{|c|c|c|c|}
\hline \multirow{2}{*}{$\begin{array}{c}\text { D.C. VOLTAGE } \\
\text { INTERRUPTION (\%) }\end{array}$} & \multirow{2}{*}{ TEST DURATION (s) } & \multicolumn{2}{|c|}{ TEST CONCLUSION } \\
\cline { 3 - 4 } & & VMIN & VMAX \\
\hline 0 & 5 & Fail & Fail \\
\hline
\end{tabular}

The relay has shown no compliance to both dc and ac voltage interruption tests.

\section{Voltage interruption testing to the ac power supply}

Table VII. - Voltage interruption test on the ac energizing input at Vmin=80 Vac and Vmax=265 Vac.

\begin{tabular}{|c|c|c|c|}
\hline AC VOLTAGE & TEST DURATION & \multicolumn{2}{|c|}{ TEST CONCLUSION } \\
\cline { 3 - 4 } INTERRUPTION (\%) & (CYCLES) & VMIN & VMAX \\
\hline 0 & 300 & Fail & Fail \\
\hline
\end{tabular}

The relay has shown no compliance to both dc and ac voltage interruption tests, as given in Table VII.

\section{E. Ripple component testing to the dc power supply}

The alternating component on a dc signal is defined as:

$$
A_{c}=100 \cdot \frac{V_{\max }-V_{\min }}{V_{d c}}
$$

where,

Vmax is the maximum instantaneous voltage;

Vmin is the minimum instantaneous voltage; and

Vdc is the dc component

A voltage ripple of $15 \%$ of the rated dc voltage, $120 \mathrm{~Hz}$ has been applied to the lowest ( $87 \mathrm{Vdc}$ ) and to the highest $(300 \mathrm{Vdc})$ dc voltage. The test result is given in Table VIII.

Table VIII. - Alternating voltage test on the dc energizing input at Vmin $=87 \mathrm{Vdc}$ and Vmax $=300 \mathrm{Vdc}$.

\begin{tabular}{|c|c|c|c|}
\hline \multirow{2}{*}{ RIPPLE (\%) } & WAVEFORM & \multicolumn{2}{|c|}{ TEST CONCLUSION } \\
\cline { 3 - 4 } & FREQUENCY (HERTZ) & VMIN & VMAX \\
\hline 15 & 120 & Pass & Pass \\
\hline
\end{tabular}

\section{F. Gradual shut-down and start-up for dc power supply}

The IEC60255-11 requires that a 60s shut-down ramp and a 60s start-up ramp with 5 min power off in between them be applied to the dc power supply in order to observe the shut-down limit and the lowest start-up voltage. The test is applied to both the dc voltage operating limits, i.e., Vmin $=87 \mathrm{Vdc}$ and $\mathrm{Vmax}=300 \mathrm{Vdc}$ and the results are shown in Table IX.

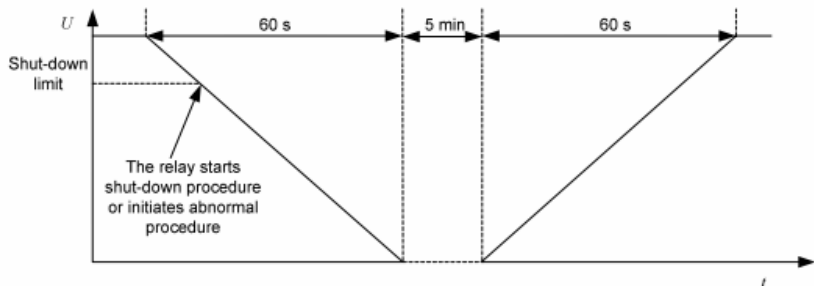

Fig. 3. Gradual shut-down / start-up test.
Table IX. - Gradual shut-down and start-up test to the dc energizing input at Vmin=87 Vdc and Vmax=300 Vdc.

\begin{tabular}{|c|c|c|}
\hline DC VOLTAGE LIMIT & VMIN (V) & VMAX (V) \\
\hline Shut-down & 63 & 63 \\
\hline Star-up & 81 & 85 \\
\hline
\end{tabular}

\section{G. Polarity inversion}

Reverse polarity for the power supply input has been applied for $1 \mathrm{~min}$. The relay has shown normal performance.

\section{Conclusion}

Performing tests on protection relays is a required practice common for relay engineers and technicians. The tests are performed in order to evaluate the relay performance and characteristics and to certify the equipment compliance to the requirements of technical standards. The numerical relays perform many functions besides protection which ought to accurate and promptly operate whenever required.

Type tests have been performed to a well known relay brand so as to evaluate whether the protection functions implemented by the relay are performed accordingly when it goes through specified sort of disturbances. The tests have been based on the international standard IEC60255-11, Edition 2.0, 2008-10 which specifies the requirements when the ac and dc power supply are energized and subjected to voltage dips, interruptions and alternating components. The relay has switched off and automatically resumed under ac and dc voltage interruptions. During the gradual shut-down test the relay has switched-off when the dc voltage has reached $63 \mathrm{Vdc}$ and started-up when the dc voltage reached $81 \mathrm{Vdc}$.

\section{Acknowledgement}

The authors thank the Brazilian agency FINEPFinanciadora de Estudos e Projetos for the financial support to this work.

\section{References}

[1] C. Labuschagne, Izak van der Merwe, "Programmability of Numerical Relays: A Busbar Protection Relay Serves as a Traditional RTU”. Schweitzer Engineering Laboratories, Inc. - SEL Publication, 8 pages.

[2] T. Sezi and B. K.Duncan, "New Intelligent Electronic Devices Change the Structure of Power Distribution Systems”, Siemens Power Transmission and Distribution, pp.944-952.

[3] IEEE WG C-2. "Protective relaying and power quality”, Draft 4, June 2003.

[4] Fan Wang, "Power Quality Disturbances and Protective Relays”. Chalmers University of Technology, Sweden. March, 2001.

[5] I. Zamora, A.J. Mazón, V. Valverde, E.Torres, A. Dysko, "Power Quality and Digital Protection 
Relays”. International Conference On Renewable Energies And Power Quality (Icrepq'04). Barcelona, 2004.

[6] IEC60255-11 Edition 2.0 2008-10, “Measuring relays and protection equipment - Part 11: Voltage dips, short interruptions, variations and ripple on auxiliary power supply port”.

[7] B.K. Duncan, B.G. Bailey, "Protection, metering, monitoring, and control of medium-voltage power systems", IEEE Transactions on Industry Applications, vol. 40, no. 1, pp. 33 - 40, Jan./Feb. 2004.

[8] Network Protection and Automation Guide (Electrical Power System), 452 pages. 